Prepared in cooperation with the Louisiana Department of Transportation and Development

\title{
Water Resources of La Salle Parish, Louisiana
}

\section{Introduction}

Information concerning the availability, use, and quality of water in La Salle Parish, Louisiana (fig. 1), is critical for proper water-supply management. The purpose of this fact sheet is to present information that can be used by water managers, parish residents, and others for stewardship of this vital resource.

Information on the availability, past and current use, use trends, and water quality from groundwater and surface-water sources in the parish is presented. Previously published reports (see References Cited section) and data stored in the U.S. Geological Survey's National Water Information System (http://waterdata. usgs.gov/nwis) are the primary sources of the information presented here.
In 2010, about 2.40 million gallons per day (Mgal/d) of water were withdrawn in La Salle Parish, including about $2.29 \mathrm{Mgal} / \mathrm{d}$ from groundwater sources and $0.10 \mathrm{Mgal} / \mathrm{d}$ from surface-water sources ${ }^{1}$ (table 1). Categories of use included public supply, rural domestic, livestock, general irrigation, and aquaculture (table 2). Water-use data collected at 5-year intervals from 1960 to 2010 (fig. 2) indicated that water withdrawals peaked in 1960 .

\footnotetext{
${ }^{1}$ Water-withdrawal data are based on estimated or reported site-specific data and aggregated data, which are distributed to sources. For a full description of water-use estimate methodology, see "Data Collection" in Sargent (2011). Tabulation of numbers in text and tables may result in different totals because of rounding; nonrounded numbers are used for calculation of totals.
}

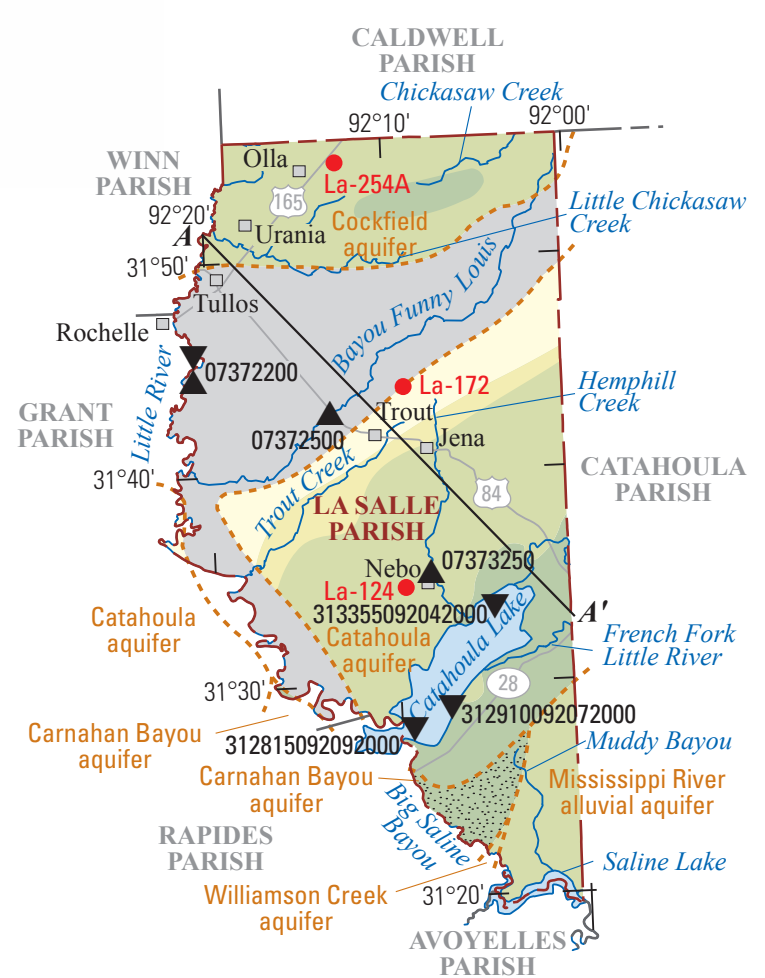

Base modified from U.S. Geological Survey digital data Albers Equal-Area Conic projection North American Datum of 1983

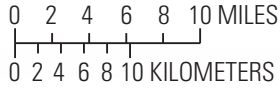

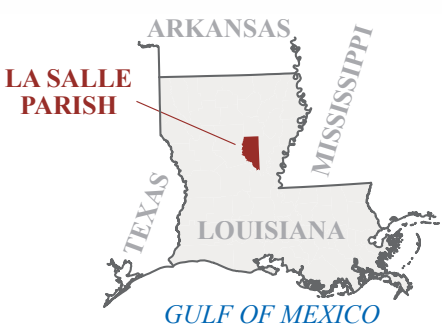

\section{EXPLANATION}

Approximate altitude of base of fresh groundwater, in feet below National Geodetic Vertical Datum of 1929 (NGVD 29) (modified from Smoot, 1988)

Above NGVD 29

0 to 49

50 to 499

500 to 899

Approximate area where no major aquifer contains freshwater

Approximate area where intermediate sands contain saltwater

- - - - Approximate boundary of area showing deepest freshwater contained within Mississippi River alluvial, Williamson Creek, Carnahan Bayou, Catahoula, and Cockfield aquifers

$A-A^{\prime}$ Line of section (see fig. 3)

Well for which hydrograph is shown (see fig. 4)

\section{U.S. Geological Survey surface-water} discharge site and number

U.S. Geological Survey surface-water quality site and number (see table 4 )

Figure 1. Location of study area, La Salle Parish, Louisiana. 
Table 1. Water withdrawals, in million gallons per day, by source in La Salle Parish, Louisiana, 2010 (Sargent, 2011; B.P. Sargent, unpub. data, 2011).

$[<$, less than $]$

\begin{tabular}{lcc}
\hline $\begin{array}{c}\text { Aquifer or surface-water } \\
\text { body }\end{array}$ & Groundwater & Surface water \\
\hline $\begin{array}{l}\text { Mississippi River alluvial } \\
\text { aquifer }\end{array}$ & $<0.003$ & \\
$\begin{array}{l}\text { Upland terrace aquifer } \\
\text { Catahoula aquifer }\end{array}$ & 1.28 & \\
Cockfield aquifer & 0.16 & \\
Miscellaneous streams & 0.86 & 0.10 \\
$\quad$ and ponds & & 0.10 \\
Total & 2.29 & \\
\hline
\end{tabular}

Table 2. Water withdrawals, in million gallons per day, by use category in La Salle Parish, Louisiana, 2010 (modified from Sargent, 2011).

\begin{tabular}{lccc}
\hline \multicolumn{1}{c}{ Use category } & Groundwater & $\begin{array}{c}\text { Surface } \\
\text { water }\end{array}$ & Total \\
\hline Public supply & 2.18 & 0.00 & 2.18 \\
Rural domestic & 0.06 & 0.00 & 0.06 \\
Livestock & 0.01 & 0.03 & 0.03 \\
General irrigation & 0.00 & 0.08 & 0.08 \\
Aquaculture & 0.06 & 0.00 & 0.06 \\
Total & 2.29 & 0.10 & 2.40 \\
\hline
\end{tabular}

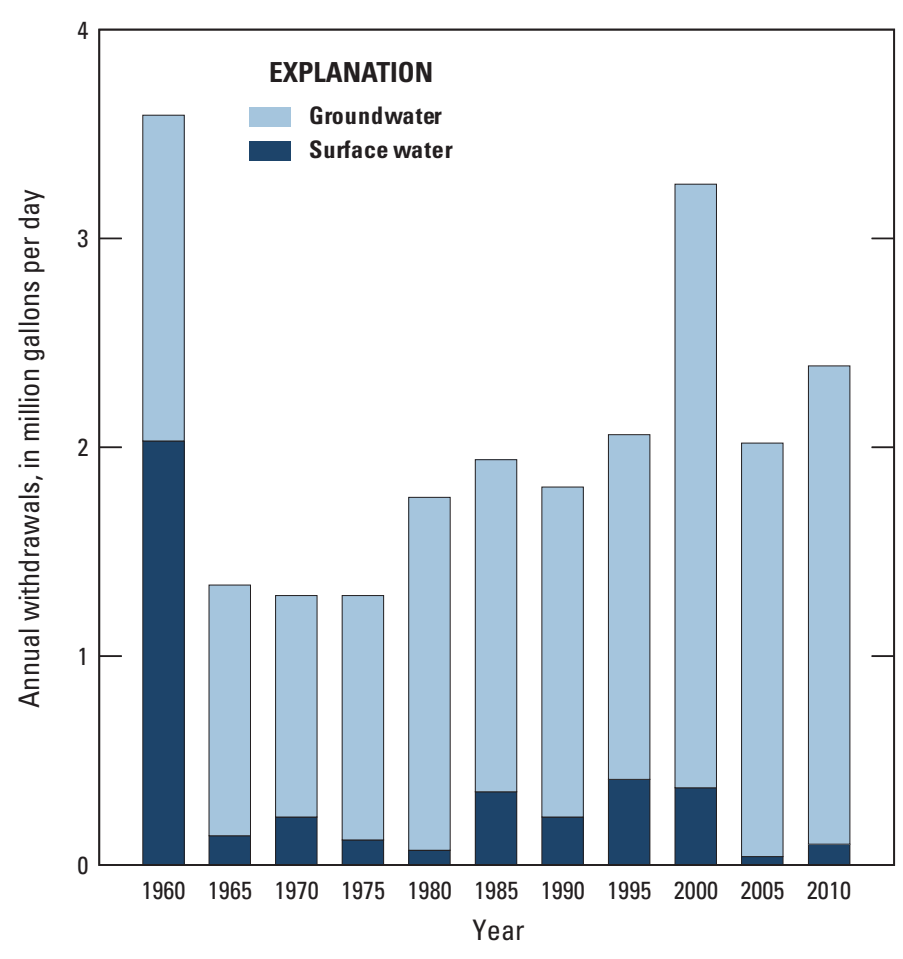

Figure 2. Water withdrawals in La Salle Parish, Louisiana, 1960-2010 (Sargent, 2011).

\section{Groundwater Resources}

Fresh groundwater (water with a chloride concentration of 250 milligrams per liter $[\mathrm{mg} / \mathrm{L}]$ or less) is generally available in La Salle Parish along the northern parish line and in central and southern parts of the parish (fig. 1). Where present, the base of freshwater is generally at depths ranging from near the National Geodetic Vertical Datum of 1929 (NGVD 29) to about 800 feet (ft) below NGVD 29 (Smoot, 1988). The primary sources of fresh groundwater in La Salle Parish are the Mississippi River alluvial, Upland terrace, Catahoula, and Cockfield aquifers (table 1). The Williamson Creek and Carnahan Bayou aquifers could also be sources of fresh groundwater in small areas of southern La Salle Parish (fig. 1); however, they will not be discussed further because no wells have been reported as screened in these aquifers. Recharge to aquifers in the parish is from precipitation, leakage from adjacent aquifers, and seasonal flow from streams. Discharge from the aquifers is by natural seasonal flow into streams, evapotranspiration, leakage into adjacent aquifers, and withdrawals from wells.

State well-registration records listed 168 active water wells screened in the primary groundwater sources in La Salle Parish in 2014, including 107 domestic, 35 public supply, 20 industrial, and 6 irrigation. In 2010, categories of use for groundwater withdrawals included public supply, rural domestic, livestock, and aquaculture (table 2) (Louisiana Department of Natural Resources, 2014).

\section{Mississippi River Alluvial Aquifer}

The Mississippi River alluvial aquifer is present near land surface in an area extending from about 2 miles (mi) northwest of Catahoula Lake southward to the southern tip of La Salle Parish. The aquifer comprises basal sand and gravel components of alluvial deposits that grade upward to silt and clay. The alluvial deposits composing the Mississippi River alluvial aquifer range in thickness from 150 to $200 \mathrm{ft}$ and overlie the Williamson Creek, Carnahan Bayou, and Catahoula aquifers. In La Salle Parish, groundwater in the Mississippi River alluvial aquifer is unconfined or semiconfined and generally moves northeast toward a topographic low near the eastern end of Catahoula Lake (Seanor and Smoot, 1995). Infiltration of precipitation through the surficial silts and clays is the primary source of recharge, with additional recharge coming from underlying aquifers and seasonal flow from streams (Whitfield, 1975).

State well-registration records listed 9 active wells screened in the Mississippi River alluvial aquifer in La Salle Parish in 2014, including 5 domestic, 2 irrigation, and 2 industrial. Well depths ranged from 24 to $220 \mathrm{ft}$ below land surface. Reported yields from wells screened in the Mississippi River alluvial aquifer in La Salle Parish ranged from 100 to 1,500 gallons per minute (gal/min; Louisiana Department of Natural Resources, 2014).

\section{Upland Terrace Aquifer}

The Upland terrace aquifer outcrops at land surface in much of central La Salle Parish, where it overlies the Catahoula aquifer (fig. 3), and in small areas in northern La Salle Parish, where it overlies the Cockfield aquifer and Vicksburg-Jackson confining layer. The Upland terrace aquifer comprises basal sands and gravels of terrace deposits that grade upward to silt 


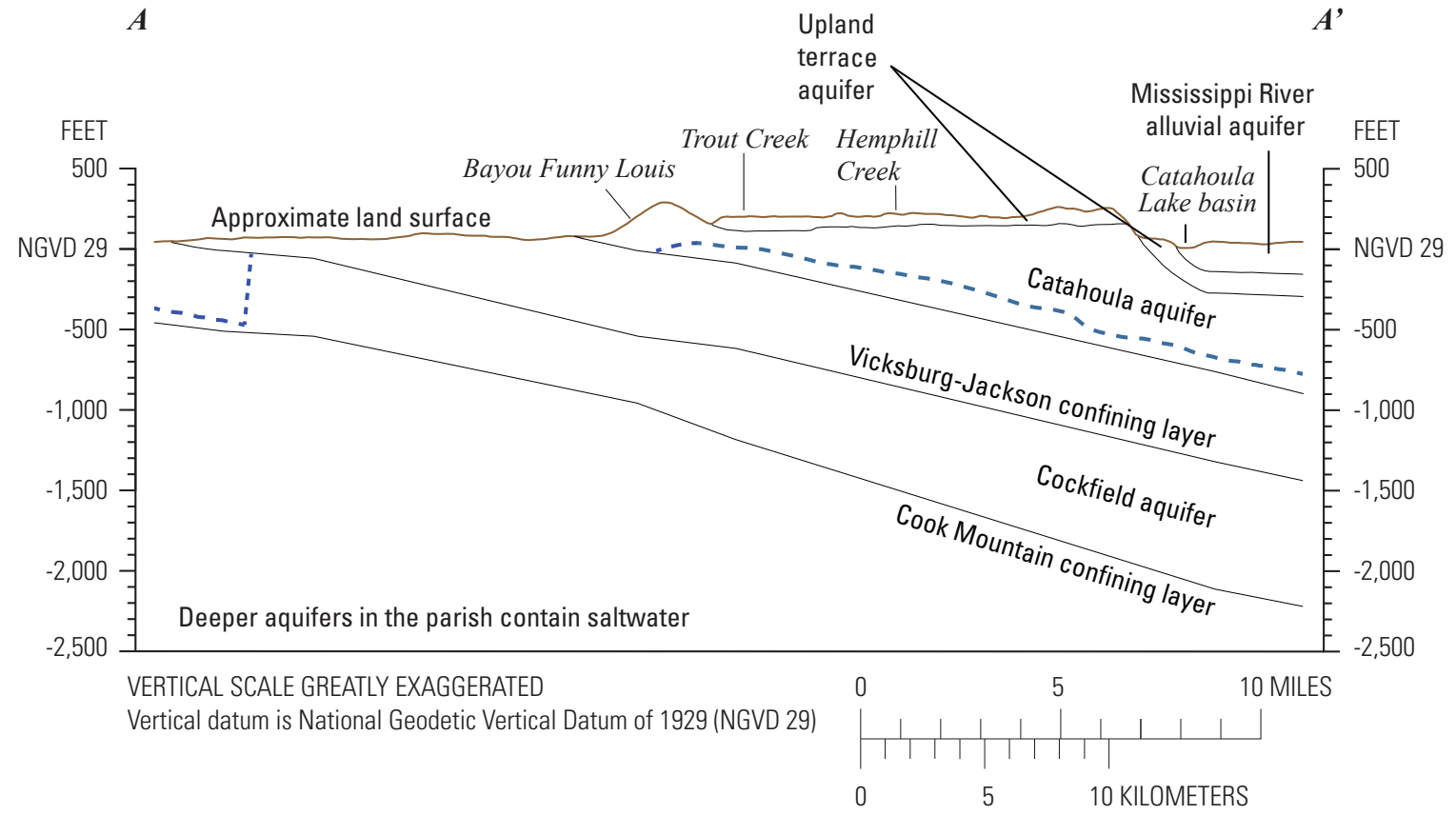

EXPLANATION
--- - Base of freshwater

Figure 3. Generalized northwest-to-southeast hydrogeologic section through La Salle Parish, Louisiana, showing aquifer and confining layer intervals (individual sand and clay layers not shown; modified from Fisk, 1938). Trace of section shown on figure 1.

and clay. In La Salle Parish, the thickness of the terrace deposits generally ranges from 30 to $50 \mathrm{ft}$ in small outcrops in northern La Salle Parish and from 100 to $150 \mathrm{ft}$ in the main outcrop area in central parts of the parish (Sloss and others, 1961). The aquifer is recharged by precipitation and is generally under water-table (unconfined) conditions. Groundwater in the aquifer moves from topographically high positions to local stream valleys (Rollo, 1960). The aquifer generally contains freshwater, but in the topographically low areas near Catahoula Lake, saltwater (water with a chloride concentration greater than $250 \mathrm{mg} / \mathrm{L}$ ) is present.

State well-registration records listed 82 active water wells screened in the Upland terrace aquifer in La Salle Parish in 2014, including 61 domestic, 17 public supply, 3 irrigation, and 1 industrial. Well depths ranged from 8 to $227 \mathrm{ft}$ below land surface. Reported yields from wells screened in the Upland terrace aquifer in La Salle Parish ranged from 2 to $350 \mathrm{gal} / \mathrm{min}$ (Louisiana Department of Natural Resources, 2014). In 2010, withdrawals from the Upland terrace aquifer in La Salle Parish totaled about 1.28 Mgal/d and included about 1.25 Mgal/d for public supply and $0.03 \mathrm{Mgal} / \mathrm{d}$ for rural-domestic use. Freshwater from the Upland terrace aquifer is generally soft ${ }^{2}$ and generally does not exceed the U.S. Environmental Protection Agency's Secondary Maximum Contaminant Levels (SMCLs) ${ }^{3}$ for color or concentrations of iron, manganese, and dissolved solids (table 3 ).

\section{Catahoula Aquifer}

The Catahoula aquifer outcrops at land surface or subcrops beneath terrace deposits across central La Salle Parish in a southwest-to-northeast direction. In La Salle Parish, the base of freshwater in the Catahoula aquifer generally ranges from near the

\footnotetext{
${ }^{2}$ Hardness ranges, expressed as milligrams per liter of calcium carbonate, are as follows: 0-60, soft; 61-120, moderately hard; 121-180, hard; greater than 180, very hard (Hem, 1985).

${ }^{3}$ The SMCLs are nonenforceable Federal guidelines regarding cosmetic effects (such as tooth or skin discoloration) or aesthetic effects (such as taste, odor, or color) of drinking water. At high concentrations or values, health implications as well as aesthetic degradation may result. SMCLs were established as guidelines for the States by the U.S. Environmental Protection Agency (1992).
}

NGVD 29 in central areas to about $800 \mathrm{ft}$ below NGVD 29 near the southern end of the parish (fig. 1). In the southwestern corner of the parish, the Catahoula aquifer contains only saltwater (fig. 1).

The Catahoula aquifer is recharged by infiltration of precipitation in outcrop areas within the parish and flow from the overlying Upland terrace aquifer. Much of the water entering the aquifer is discharged to nearby streams, but some may be lost to evapotranspiration. Water that is not discharged locally moves downgradient southward toward discharge areas at lower altitudes and toward the Little River Valley (Martin and Whiteman, 1986). Water levels in the Catahoula aquifer in La Salle Parish fluctuate annually but showed little increase or decrease from 2002 to 2012, as illustrated by water levels in well La-172 (fig. 4), located in the outcrop area about 4 mi north of Jena, and in well La-124, located about 6 mi south of Jena (fig. 1).

State well-registration records listed 38 active water wells screened in the Catahoula aquifer in La Salle Parish in 2014, including 25 domestic, 9 public supply, 3 industrial, and 1 irrigation. Well depths ranged from 21 to $873 \mathrm{ft}$ below land surface. Reported yields from wells screened in the Catahoula aquifer in La Salle Parish ranged from 24 to $350 \mathrm{gal} / \mathrm{min}$ (Louisiana Department of Natural Resources, 2014). In 2010, withdrawals from the Catahoula aquifer in La Salle Parish totaled about $0.16 \mathrm{Mgal} / \mathrm{d}$ and included about $0.08 \mathrm{Mgal} / \mathrm{d}$ for public supply, $0.05 \mathrm{Mgal} / \mathrm{d}$ for aquaculture, and $0.03 \mathrm{Mgal} / \mathrm{d}$ for ruraldomestic use and livestock. A statistical summary of selected water-quality characteristics for freshwater samples collected from 44 wells screened in the Catahoula aquifer in La Salle Parish is presented in table 3 .

\section{Cockfield Aquifer}

The Cockfield aquifer is present throughout La Salle Parish but contains freshwater only in a roughly 3-7-mi-wide band along the northern parish line where the altitude of the base of freshwater ranges from about 300 to greater than $500 \mathrm{ft}$ below NGVD 29 (fig. 1). The Cockfield aquifer is overlain by clays of the VicksburgJackson confining layer throughout most of the parish (fig. 3) but outcrops at land surface near Olla (fig. 1) in the northwestern 
Table 3. Summary of selected water-quality characteristics of freshwater in the Upland terrace, Catahoula, and Cockfield aquifers in La Salle Parish, Louisiana (U.S. Geological Survey, 2013c).

[Values are in milligrams per liter, except as noted. ${ }^{\circ} \mathrm{C}$, degrees Celsius; PCU, platinum cobalt units; $\mu \mathrm{S} / \mathrm{cm}$, microsiemens per centimeter; SU, standard units; $\mathrm{CaCO}_{3}$, calcium carbonate; $\mu \mathrm{g} / \mathrm{L}$, micrograms per liter; <, less than; SMCL, Secondary Maximum Contaminant Level established by the U.S. Environmental Protection Agency (2012); NA, not applicable]

\begin{tabular}{|c|c|c|c|c|c|c|c|c|c|}
\hline & $\begin{array}{c}\text { Temperature } \\
\left({ }^{\circ} \mathrm{C}\right)\end{array}$ & $\begin{array}{l}\text { Color } \\
\text { (PCU) }\end{array}$ & $\begin{array}{c}\text { Specific } \\
\text { conductance, } \\
\text { field } \\
(\mu \mathrm{S} / \mathrm{cm} \text { at } \\
\left.25^{\circ} \mathrm{C}\right)\end{array}$ & $\begin{array}{l}\mathrm{pH}, \\
\text { field } \\
\text { (SU) }\end{array}$ & $\begin{array}{l}\text { Hardness } \\
\text { (as } \mathrm{CaCO}_{3} \text { ) }\end{array}$ & $\begin{array}{l}\text { Chloride, } \\
\text { filtered } \\
\text { (as CI) }\end{array}$ & $\begin{array}{c}\text { Iron, } \\
\text { filtered } \\
(\mu \mathrm{g} / \mathrm{L} \\
\text { as Fe) }\end{array}$ & $\begin{array}{c}\text { Man- } \\
\text { ganese, } \\
\text { filtered } \\
(\mu \mathrm{g} / \mathrm{L} \\
\text { as Mn) }\end{array}$ & $\begin{array}{l}\text { Dissolved } \\
\text { solids, } \\
\text { filtered }\end{array}$ \\
\hline \multicolumn{10}{|c|}{ Upland terrace aquifer, 1939-84 (72 wells) } \\
\hline Median & 19.8 & 0 & 62 & 6.4 & 15 & 9.8 & 90 & 25 & 74 \\
\hline 10th percentile & 19.0 & 0 & 39 & 5.5 & 6 & 3.1 & 27 & $<10$ & 53 \\
\hline 90th percentile & 20.5 & 10 & 193 & 6.9 & 60 & 50 & 700 & 87 & 151 \\
\hline Number of samples & 12 & 39 & 39 & 39 & 72 & 72 & 38 & 34 & 39 \\
\hline $\begin{array}{l}\text { Percentage of } \\
\text { samples that do } \\
\text { not exceed SMCLs }\end{array}$ & NA & 97 & NA & 41 & NA & 100 & 87 & 82 & 97 \\
\hline \multicolumn{10}{|c|}{ Catahoula aquifer, 1945-83 (44 wells) } \\
\hline Median & 21.5 & 5 & 296 & 7.6 & 15 & 10 & 120 & 50 & 268 \\
\hline 10th percentile & 19.8 & 0 & 108 & 6.4 & 2 & 4.1 & 30 & 26 & 130 \\
\hline 90th percentile & 21.6 & 17 & 860 & 8.0 & 32 & 110 & 370 & 100 & 584 \\
\hline Number of samples & 9 & 23 & 24 & 23 & 44 & 44 & 22 & 9 & 26 \\
\hline $\begin{array}{l}\text { Percentage of } \\
\text { samples that do } \\
\text { not exceed SMCLs }\end{array}$ & NA & 87 & NA & 83 & NA & 100 & 77 & 56 & 81 \\
\hline \multicolumn{10}{|c|}{ Cockfield aquifer, 1939-85 (39 wells) } \\
\hline Median & 21.0 & 100 & 1,130 & 8.4 & 8 & 35 & 110 & 30 & 622 \\
\hline 10th percentile & 20.0 & 5 & 655 & 7.7 & 0.5 & 11 & 56 & $<10$ & 426 \\
\hline 90th percentile & 22.0 & 240 & 1,468 & 8.7 & 225 & 79 & 240 & 380 & 817 \\
\hline Number of samples & 11 & 26 & 29 & 19 & 36 & 39 & 19 & 10 & 24 \\
\hline $\begin{array}{l}\text { Percentage of } \\
\text { samples that do } \\
\text { not exceed SMCLs }\end{array}$ & NA & 27 & NA & 79 & NA & 100 & 89 & 80 & 38 \\
\hline \multicolumn{10}{|c|}{ SMCLs } \\
\hline & NA & 15 & NA & $6.5-8.5$ & NA & 250 & 300 & 50 & 500 \\
\hline
\end{tabular}

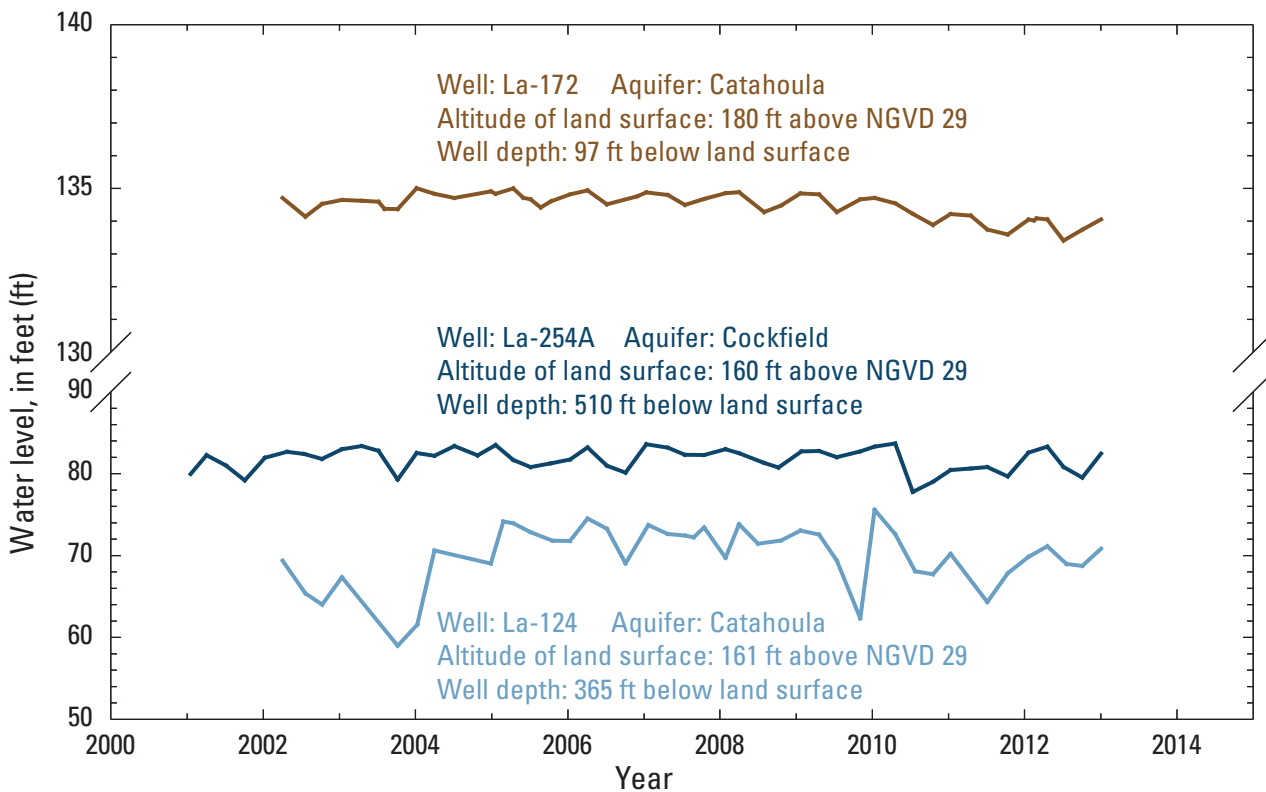

Figure 4. Water levels in wells La-124 and La-172 screened in the Catahoula aquifer and well La-254A screened in the Cockfield aquifer in La Salle Parish, Louisiana (see fig. 1 for well locations; U.S. Geological Survey, 2013a). Altitude of land surface and water levels are measured in feet (ft) above the National Geodetic Vertical Datum of 1929 (NGVD 29). 
corner of the parish. The aquifer dips to the southeast, and the altitude of the base of the aquifer ranges from about $400 \mathrm{ft}$ above NGVD 29 in the northwestern corner of the parish to more than 2,000 ft below NGVD 29 in the southeastern corner. Aquifer thickness ranges from about 400 to $800 \mathrm{ft}$ in the freshwater area along the northern parish line (Ryals, 1984).

Recharge to the aquifer is primarily from infiltration of precipitation in areas where the aquifer outcrops in La Salle, Winn, Caldwell, and Jackson Parishes and other parishes to the north. The direction of groundwater flow in the Cockfield aquifer in La Salle Parish is generally to the south or southeast (Brantly and Seanor, 1996). Discharge from the aquifer is to local streams in the outcrop area, by evapotranspiration, by wells, and by seepage through the confining layer to overlying aquifers in areas where the aquifer is confined. The clayey confining layers above and below the aquifer have impeded flushing of saltwater from the aquifer downgradient (Rollo, 1960). The water level in well La-254A, located in northern La Salle Parish (fig. 1) and screened $510 \mathrm{ft}$ below land surface in the Cockfield aquifer, fluctuates annually, but water levels have remained relatively stable since 2001 (fig. 4).

State well-registration records listed 39 active wells screened in the Cockfield aquifer in La Salle Parish in 2014, including 16 domestic, 14 industrial, and 9 public supply. Well depths ranged from 25 to $1,665 \mathrm{ft}$ below land surface. Reported yields from wells screened in the Cockfield aquifer in La Salle Parish ranged from 3 to $335 \mathrm{gal} / \mathrm{min}$ (Louisiana Department of Natural Resources, 2014). Water withdrawals from the Cockfield aquifer in La Salle Parish totaled about 0.86 Mgal/d in 2010 (table 1) and included about $0.85 \mathrm{Mgal} / \mathrm{d}$ for public supply and $0.01 \mathrm{Mgal} / \mathrm{d}$ for rural-domestic use. A statistical summary of selected waterquality characteristics of freshwater from 39 wells screened in the Cockfield aquifer in La Salle Parish is presented in table 3. In general, samples did not exceed the SMCLs for concentrations of chloride, iron, and manganese but did exceed SMCLs for color and concentrations of dissolved solids.

\section{Surface-Water Resources}

In 2010, about $0.10 \mathrm{Mgal} / \mathrm{d}$ of surface water were withdrawn in La Salle Parish (table 2). Notable surface-water bodies in the parish include the Little River, Bayou Funny Louis, Chickasaw and Little Chickasaw Creeks, Hemphill Creek, Trout Creek, Saline Lake, Muddy Bayou, Big Saline Bayou, French Fork Little River, and Catahoula Lake (fig. 1).

Discharge data for streams in La Salle Parish are limited; however, during 1978-95, Hemphill Creek at Nebo (site number 07373250; fig. 1) had an average daily discharge of 63 cubic feet per second $\left(\mathrm{ft}^{3} / \mathrm{s}\right)$ from a drainage area of 35 square miles $\left(\mathrm{mi}^{2}\right)$. During 1939-70, Bayou Funny Louis near Trout (site number 07372500; fig. 1) had an average daily discharge of $123 \mathrm{ft}^{3} / \mathrm{s}$ from a drainage area of $92 \mathrm{mi}^{2}$ (U.S. Geological Survey, 2013b). During 1958-96 and 1998-2011, the Little River near Rochelle (site number 07372200; fig. 1) had an average discharge of 2,182 $\mathrm{ft}^{3} / \mathrm{s}$ from a drainage area of 1,899 $\mathrm{mi}^{2}$ (U.S. Geological Survey, 2012).

Water samples collected during 1964-86 indicated that water in the Little River near Rochelle is generally soft and generally does not exceed SMCLs for $\mathrm{pH}$ and concentrations of chloride and sulfate (table 4). Dissolved oxygen concentration is generally greater than $5 \mathrm{mg} / \mathrm{L}$, which is considered the minimum value for a diversified population of fresh, warmwater biota, including sport fish (Louisiana Department of Environmental Quality, 2008).
Catahoula Lake is the largest natural inland freshwater lake in Louisiana, covering more than $46 \mathrm{mi}^{2}$. The lake, located on the Little River (fig. 1), is a principal stopover and wintering area for hundreds of thousands of migratory waterfowl and shorebirds. The management plan for the lake includes maintaining seasonal trends of winter and spring high water and summer and fall drawdown, primarily to provide optimal habitat for migratory birds (Doyle and others, 2002). Water samples from Catahoula Lake, which were analyzed during the period 1976-78, are presented in table 4. The median value for hardness fell into the soft range, dissolved oxygen concentrations were generally greater than $5 \mathrm{mg} / \mathrm{L}$, and the median value for manganese was $90 \mathrm{mg} / \mathrm{L}$.

\section{References Cited}

Brantly, J.A., and Seanor, R.C., 1996, Louisiana ground-water map no. 9 Potentiometric surface, 1993, and water-level changes, 1968-93, of the Cockfield aquifer in northern Louisiana: U.S. Geological Survey Water-Resources Investigations Report 95-4241, 2 sheets, accessed January 24, 2012, at http:// pubs.er.usgs.gov/publication/wri954241

Doyle, T.W., Michot, T.C., and Wells, C.J., 2002, Modeling the bathymetry of Catahoula Lake-Specialized technology for wetland management: U.S. Geological Survey Fact Sheet 098-02, 2 p., accessed January 22, 2013, at http:// pubs.er.usgs.gov/publication/fs09802.

Fisk, H.N., 1938, Geology of Grant and La Salle Parishes: Department of Conservation, Louisiana Geological Survey Geological Bulletin no. 10, 246 p.

Hem, J.D., 1985, Study and interpretation of the chemical characteristics of natural water (3d ed.): U.S. Geological Survey Water-Supply Paper 2254, 264 p., accessed February 20, 2013, at http://pubs.er.usgs.gov/publication/wsp2254.

Louisiana Department of Environmental Quality, 2008, Environmental Regulatory Code, Title 33, Part IX, Subpart 1: Baton Rouge, Louisiana Department of Environmental Quality, accessed December 27, 2012, at http:www.deq.louisiana. gov/portal/tabid/1674/Default.aspx.

Louisiana Department of Natural Resources, 2014, Strategic Online Natural Resources Information System (SONRIS): Louisiana Department of Natural Resources database, accessed November 13, 2014, at http://sonris.com/.

Martin, Angel, Jr., and Whiteman, C.D., Jr., 1986, Generalized potentiometric surface of the Catahoula aquifer in central Louisiana, 1980: U.S. Geological Survey Water-Resources Investigations Report 86-4059, 1 sheet.

Rollo, J.R., 1960, Ground water in Louisiana: Department of Conservation, Louisiana Geological Survey, and Louisiana Department of Public Works Water Resources Bulletin no. 1, 84 p.

Ryals, G.N., 1984, Regional geohydrology of the northern Louisiana salt-dome basin, part II, geohydrologic maps of the Tertiary aquifers and related confining layers: U.S. Geological Survey Water-Resources Investigations Report 83-4135, 6 p., accessed December 27, 2012, at http://pubs.er.usgs.gov/publication/ wri834135.

Sargent, B.P., 2011, Water use in Louisiana, 2010: Louisiana Department of Transportation and Development Water Resources Special Report no. 17, 135 p.

Seanor, R.C., and Smoot, C.W., 1995, Louisiana ground-water map no. 6 Potentiometric surface, 1990, and water-level changes, 1974-90, of the Mississippi River alluvial aquifer in northeastern Louisiana: U.S. Geological Survey Water-Resources Investigations Report 95-4146, 2 sheets.

Sloss, Raymond, and May, H.G., 1961, Water, in La Salle Parish resources and facilities: Louisiana Department of Public Works and La Salle Parish Development Board, p. 47-57.

Smoot, C.W., 1988, Louisiana hydrologic atlas map no. 3-Altitude of the base of freshwater in Louisiana: U.S. Geological Survey Water-Resources Investigations Report 86-4314, 1 sheet, accessed December 27, 2012, at http://pubs.er.usgs.gov/ publication/wri864314.

U.S. Environmental Protection Agency, 1992, Secondary drinking water regulations-Guidance for nuisance chemicals: U.S. Environmental Protection Agency publication EPA 810/K-92-001, 4 p., accessed December 27, 2012, at http://water.epa.gov/drink/contaminants/secondarystandards.cfm. 
Table 4. Summary of selected water-quality characteristics for Little River near Rochelle and Catahoula Lake at three locations in La Salle Parish, Louisiana (U.S. Geological Survey, 2013c).

[Values are in milligrams per liter, except as noted. PCU, platinum cobalt units; $\mu \mathrm{S} / \mathrm{cm}$, microsiemens per centimeter; ${ }^{\circ} \mathrm{C}$, degrees Celsius; SU, standard units; $\mathrm{CaCO}_{3}$, calcium carbonate; $\mu \mathrm{g} / \mathrm{L}$, micrograms per liter; SMCL, Secondary Maximum Contaminant Level established by the U.S. Environmental Protection Agency (2012); NA, not applicable]

\begin{tabular}{|c|c|c|c|c|c|c|c|c|c|c|c|}
\hline & $\begin{array}{l}\text { Color } \\
\text { (PCU) }\end{array}$ & $\begin{array}{c}\text { Specific } \\
\text { conductance, } \\
\text { field }(\mu \mathrm{S} / \mathrm{cm} \\
\left.\text { at } 25^{\circ} \mathrm{C}\right)\end{array}$ & $\begin{array}{l}\text { Oxygen, } \\
\text { dis- } \\
\text { solved }\end{array}$ & $\begin{array}{l}\mathrm{pH}, \\
\text { field } \\
\text { (SU) }\end{array}$ & $\begin{array}{c}\text { Hard- } \\
\text { ness (as } \\
\mathrm{CaCO}_{3} \text { ) }\end{array}$ & $\begin{array}{l}\text { Calcium, } \\
\text { filtered } \\
\text { (as Ca) }\end{array}$ & $\begin{array}{c}\text { Chloride, } \\
\text { filtered } \\
\text { (as CI) }\end{array}$ & $\begin{array}{l}\text { Iron, } \\
\text { filtered, } \\
(\mu \mathrm{g} / \mathrm{L} \text { as } \\
\mathrm{Fe})\end{array}$ & $\begin{array}{l}\text { Man- } \\
\text { ganese, } \\
\text { filtered } \\
\text { ( } \mu \mathrm{g} / \mathrm{L} \text { as } \\
\mathrm{Mn})\end{array}$ & $\begin{array}{l}\text { Sulfate, } \\
\text { filtered } \\
\text { (as } \mathrm{SO}_{4} \text { ) }\end{array}$ & $\begin{array}{l}\text { Dis- } \\
\text { solved } \\
\text { solids }\end{array}$ \\
\hline \multicolumn{12}{|c|}{ Little River near Rochelle, 1964-86¹ } \\
\hline Median & 100 & 314 & 7.0 & 6.7 & 30 & 8.1 & 56 & 380 & 185 & 17 & 225 \\
\hline 10th percentile & 40 & 81 & 4.9 & 6.1 & 14 & 4.0 & 8.9 & 180 & 71 & 8.6 & 73.6 \\
\hline 90th percentile & 200 & 1,750 & 10.0 & 7.4 & 90 & 20 & 620 & 940 & 445 & 69 & 1,734 \\
\hline $\begin{array}{c}\text { Number of } \\
\text { samples }\end{array}$ & 225 & 234 & 140 & 211 & 202 & 196 & 204 & 36 & 32 & 205 & 214 \\
\hline $\begin{array}{l}\text { Percentage of } \\
\text { samples that } \\
\text { do not exceed } \\
\text { SMCLs }\end{array}$ & 1 & NA & NA & 68 & NA & NA & 84 & 39 & 9 & 99 & 75 \\
\hline \multicolumn{12}{|c|}{ Catahoula Lake at three locations, $1976-78^{2}$} \\
\hline Median & 90 & 173.5 & 9.1 & 7.0 & 27 & 7.2 & 26 & 170 & 90 & 18.5 & 106 \\
\hline 10th percentile & 70 & 94.9 & 6.8 & 6.4 & 17.8 & 5.1 & 13 & 109 & 28 & 8.3 & 75.9 \\
\hline 90th percentile & 102 & 446.3 & 10.8 & 7.4 & 38.3 & 11 & 80.2 & 350 & 146 & 54.1 & 262.9 \\
\hline $\begin{array}{c}\text { Number of } \\
\text { samples }\end{array}$ & 20 & 20 & 20 & 20 & 20 & 20 & 20 & 20 & 19 & 20 & 20 \\
\hline $\begin{array}{l}\text { Percentage of } \\
\text { samples that } \\
\text { do not exceed } \\
\text { SMCLs }\end{array}$ & 0 & NA & NA & 85 & NA & NA & 100 & 85 & 26 & 100 & 100 \\
\hline \multicolumn{12}{|c|}{ SMCLs } \\
\hline & 15 & NA & NA & $6.5-8.5$ & NA & NA & 250 & 300 & 50 & 250 & 500 \\
\hline
\end{tabular}

${ }^{1}$ Site number 07372200 .

${ }^{2}$ Datasets from sites $312815092092000,312910092072000,313355092042000$.

U.S. Environmental Protection Agency, 2012, 2012 Edition of the drinking water standards and health advisories: U.S. Environmental Protection Agency publication EPA 822-S-12-001, Office of Water, 12 p., accessed December 27, 2012, at http://water.epa.gov/action/advisories/drinking/upload/ dwstandards2012.pdf.

U.S. Geological Survey, 2012, Water-resources data for the United States, water year 2011, site 07372200: U.S. Geological Survey Water-Data Report WDR-US-2011, accessed January 18, 2013, at http://wdr.water.usgs.gov/ wy2011/pdfs/07372200.2011.pdf.

U.S. Geological Survey, 2013a, Groundwater levels for Louisiana: National Water Information System Web Interface, accessed January 15, 2013, at http://nwis. waterdata.usgs.gov/la/nwis/gwlevels.

U.S. Geological Survey, 2013b, Surface-water daily statistics for the Nation: National Water Information System Web Interface, accessed September 25, 2013, at http://waterdata.usgs.gov/nwis/nwisman/.

U.S. Geological Survey, 2013c, Water quality samples for Louisiana: National Water Information System Web Interface, accessed January 15, 2013, at http:// nwis.waterdata.usgs.gov/la/nwis/qwdata.

Whitfield, M.S., Jr., 1975, Geohydrology and water quality of the Mississippi River alluvial aquifer, northeastern Louisiana: Louisiana Department of Public Works Water Resources Technical Report no. 10, 29 p.
This fact sheet was published by the U.S. Geological Survey, in cooperation with the Louisiana Department of Transportation and Development (DOTD). Thanks are given to Zahir "Bo" Bolourchi, Director, Water Resources Programs, DOTD, who contributed to the content of the fact sheet.

\section{By Vincent E. White and Lawrence B. Prakken}

\section{For additional information, contact:}

Director, USGS Lower Mississippi-Gulf Water Science Center 3535 S. Sherwood Forest Blvd., Suite 120

Baton Rouge, LA 70816

E-mail: gs-w-lmg_center_director@usgs.gov

Fax: (225) 298-5490

Telephone: (225) 298-5481

Home Page: http://la.water.usgs.gov 